$<$ http://zakon4.rada.gov.ua/laws/show/324/95-вр> (Accessed 15 October 2020). (in Ukrainian).

Стаття надійшла до редакції 02.11.2020.

\title{
O. Makara
}

A. Kotinsky

\section{COMPETITION CONDITIONED STRATEGIC DECISION MAKING BY TOURISM ENTERPRISES IN UKRAINE}

The article is devoted to the disclosure of theoretical and methodological foundations and development of practical recommendations for strategic tourism management in Ukraine. The main components of an effective strategy in the field of tourism are identified as well as the main levels of tourism development and appropriate tools for implementing this development.

The authors have analysed the process of strategic decision making by enterprises in the field of tourism in a competitive environment. The strategies of tourism enterprises should be the basic provisions creating a hierarchical system with intertwined elements. This system should be in line with the national strategy for the development of tourism in Ukraine, combining macro-, meso-, and micro-levels.

The ratified Programme of the sphere of tourism development of Volyn region exemplifies the practice of development and realisation programme and strategy by local authorities in the field of tourism. It has been concluded that coordination and control over the implementation of the Programme remain unsettled. Apart from the development measures and sources of funding the strategies for tourism development in the regions of Ukraine should also provide appropriate mechanisms for control, monitoring and reporting.

The study of tourism has shown that this industry is currently experiencing at the stage of development, which is due to the long process of reforming Ukraine's economy. In this connection, the author has proposed the following measures aimed at withdrawing the tourism sector out of development: achieving European and world parameters of the balance of service quality and prices for these services; development of market mechanisms in the field of tourism; development of tourism in a mixed form of ownership; raising funds from the tourist structures independently, as well as bank loans and investments; development of an investments protecting mechanism, including the foreign ones; creation of a favourable tax policy to support tourism development, intensification of environmental activities to create normal living conditions and environmental safety of the territory; creation of programmes and further prognosticating the sphere of tourism development

Key words: strategy, strategic decision making, tourism sphere, competitiveness, management.

УДК 338.48

О.В. Макара

В.М. Майборода

\section{СУЧАСНИЙ СТАН ТА ОСОБЛИВОСТІ РОЗВИТКУ МЕНЕДЖМЕНТУ ТУРИЗМУ}

Розглянуто систему менеджменту туризму як сукупність взаємопов'язаних елементів, щзо взаємодіють між собою. Розкрито сутність складових менеджменту туризму та їх функиіонування. Розглянуто концепцію розвитку менеджменту туризму 
i програмні документи туристичної галузі. Акцентується увага на туристичній дестинаці. визначенні менеджменту дестинації.

Ключові слова: розвиток менеджменту туризму, елементи менеджменту, фактори впливу, туристична дестинація, концепџія конкурентоспроможності дестинації, стратегія менеджменту туризму.

DOI 10.34079/2226-2822-2020-10-20-55-61

Постановка проблеми. Розвиток туризму в економіці країни $є$ визначальним у сфері послуг, оскільки завдяки туристичній галузі можна покращити соціально орієнтовану ринкову систему в цілому, адже він може забезпечувати створення нових робочих місць, розвиток середнього та малого бізнесу, збереження та відновлення природних територій, зростання доходів, надходження валютних коштів до бюджетів усіх рівнів, розвиток інфраструктури тощо.

Економічна, соціальна, екологічна роль туризму на сучасному етапі визначає необхідність формування комунікацій із усіма активними учасниками сфери туризму як усередині країни, так і за ії межами. Для організації ефективної роботи щодо просування і забезпечення туристичної дестинації потрібно формувати нові підходи до управління.

Аналіз останніх досліджень та публікацій. У процесі дослідження вивчені ключові положення теорій і моделей відомих зарубіжних дослідників менеджменту туризму: Р. Батлера, Ф. Котлера, Н. Лейпера, Е. Лоуза, Д. МакКеннелла, С. Пайка, Б. Річі, В. Фрамке, С. Хадсона, та ін.

Значний внесок в концептуалізацію менеджменту туризму і розробку проблем розвитку туристично-рекреаційних територій внесли такі українські вчені: О. А. Гвозденко, В. Г. Банько, В. Ф. Данильчук, Л. П. Дядечко, Г. І. Михайличенко, В. Є. Редько, І. Г. Смирнов, $\quad$ Т. І. Ткаченко та ін. Проблемами визначення дестинації як головного елементу сфери туризму займалися Н. Купер, В. Матієсон, Ф. Пірс, Д.Флетчер та ін.

Визнаючи значний внесок вітчизняних вчених, варто відзначити, що в даний час все ще проведено недостатньо наукових досліджень, що представляють концепцію менеджменту туризму, яка враховує його багатоаспектність.

Виклад основного матеріалу. Специфіка туристичного обслуговування, мультиплікативний ефект туризму вимагають відповідного підходу до особливостей планування, організації, мотивації, контролю функціонування підприємств туристичної сфери. Водночас це $є$ основою інституційно-організаційної системи туризму, яка відповідає за менеджмент. В такому аспекті менеджмент туризму визначається як управління процесами, які відіграють важливе значення в індустрії туризму.

Менеджмент має починатись 3 формування концепції, яка несе наповнення перетворень. Наявність концепції розвитку менеджменту туризму на національному рівні може служити ознакою галузевої політики. Формуванню такої концепції повинні передувати стратегія менеджменту туризму.

Така стратегія на даний момент існує. Відповідно до вимог та проблем розвитку сфери туризму урядом схвалено Стратегію розвитку туризму та курортів на період до 2026 року (далі - Стратегія-2026).

Головна мета реалізації Стратегії-2026 є «формування сприятливих умов для активізації розвитку сфери туризму та курортів згідно з міжнародними стандартами якості та з урахуванням європейських цінностей, перетворення іiі на високорентабельну, інтегровану у світовий ринок конкурентоспроможну сферу, що забезпечує прискорення соціально-економічного розвитку регіонів і держави в цілому, сприяє підвищенню якості 
життя населення, гармонійному розвитку і консолідації суспільства, популяризації України у світі» [1].

Для досягнення цілей Стратегії-2026 відповідно до пріоритетних напрямів визначено механізми державного регулювання розвитку сфери туризму та курортів, які мають ефективно взаємодіяти: правовий, організаційний, економічний та фінансовий.

Позитивною стороною Стратегії-2026, на думку автора, є акцент у розвитку сфери туризму на внутрішній туризм, що є правильним економічним і соціальним рішенням, тому що в існуючому вигляді внутрішній туристичний продукт прийнятний за ціною і якістю більшою мірою саме для українського туриста.

Стратегія передбачає, що до 2026 року в Україні: кількость іноземних туристів збільшиться у 2,5 раза; кількість внутрішніх туристів збільшиться в 5 разів; кількість робочих місць у сфері туризму збільшиться в 5 разів; наповнення бюджетів усіх рівнів від провадження туристичної діяльності збільшиться в 10 разів; кількість суб'єктів туристичної діяльності зросте в 5 разів; туристи витрачатимуть під час подорожей в Україні до 80 млрд грн; буде створено позитивний імідж України як країни, привабливої для туризму [1].

На думку автора, Стратегія-2026 має також недоліки, які необхідно врахувати в концепції розвитку менеджменту туризму:

- у Стратегії визначено основні напрямки вдосконалення регулювання галузі та підвищення якості туристичних послуг (нормативно-правова база сфери туризму та курортів; розвиток туристичної інфраструктури; маркетингова політика розвитку туризму та курортів України; розвиток людських ресурсів; безпека туристів), але практично не порушені екологічні проблеми, зокрема потепління клімату, вплив на екологію розвитку туризму в Україні, заходи щодо подолання негативних наслідків розвитку туризму на навколишне середовище. Відповідні наслідки потрібно брати до уваги на стадії розробки стратегічних документів і проводити постійний моніторинг в процесі їх реалізації;

- відсутній проектний підхід в розробці Стратегії, а саме іiі передбачувана ефективність, форми державно-приватного партнерства в iï реалізації. Практично не застосовується бюджетування (дохідна і видаткова частина) в обгрунтуванні основних напрямків розвитку туризму в Україні.

Форммування ефективної системи розвитку менеджменту туризму відводить ключову роль туристичній дестинації, виконання якої можливе за умови залучення до цього процесу усів стейкхолдерів туризму

Поняття «дестинації» вперше з'явилося в межах системного підходу до вивчення туризму. Система туризму, згідно з загальновизнаною моделі Н. Лейпера вимагає наявності як мінімум п'яти взаємозалежних елементів [2]: туристів; регіону генерації туристів; транзитного регіону; туристської дестинації; туристичної індустрії.

К. Купер зазначає, що планування та менеджмент є єдиним механізмом об'єднання стейкхолдерів (зацікавлених сторін у розвитку туризму) та забезпечення стратегічного розвитку дестинації, що враховує економічний, екологічний і соціальний вплив туризму [3].

3 метою застосування до туристської дестинації інструментів менеджменту нашій країні варто вести активне співробітництво 3 міжнародними туристичними організаціями, зокрема 3 Міжнародною організацією 3 менеджменту дестинації (Destination Management Organisations - DMOs).

Міжнародна організація 3 менеджменту дестинації (Destination Management Organisations - DMOs) здійснює свої функції і вирішує стратегічні завдання, в тому числі раціонально управляє ресурсами і забезпечує інтереси всіх стейкхолдерів (туристів; туроператорів; великих, середніх і малих туристських підприємств; державного сектора 
і органів влади; місцевого населення) та $\epsilon$ системою менеджменту туризму на національному, регіональному та локальному рівнях.

Міжнародна практика менеджменту дестинацій показує, що досягнення високого рівня розвитку багато в чому залежить від здатності органів державної влади вибудувати ефективний механізм прийняття й реалізації рішень, спрямованих на досягнення стратегічної цілі. Тому особливе місце при розробці стратегії розвитку регіональних туристичних дестинацій повинно займати застосування програмноцільового методу управління, який орієнтований на досягнення кінцевого результату в логіці поетапної дії: формування дерева цілей, розробку адекватної виконуючої програми, реалізації управляючої програми [4].

Зарубіжні вчені Б. Річі і Дж. Крауч розглянули концептуальну модель конкурентоспроможності дестинації, де відображено вплив макро- і мікросередовища на систему менеджменту дестинації (рис. 1) [5, с. 3].

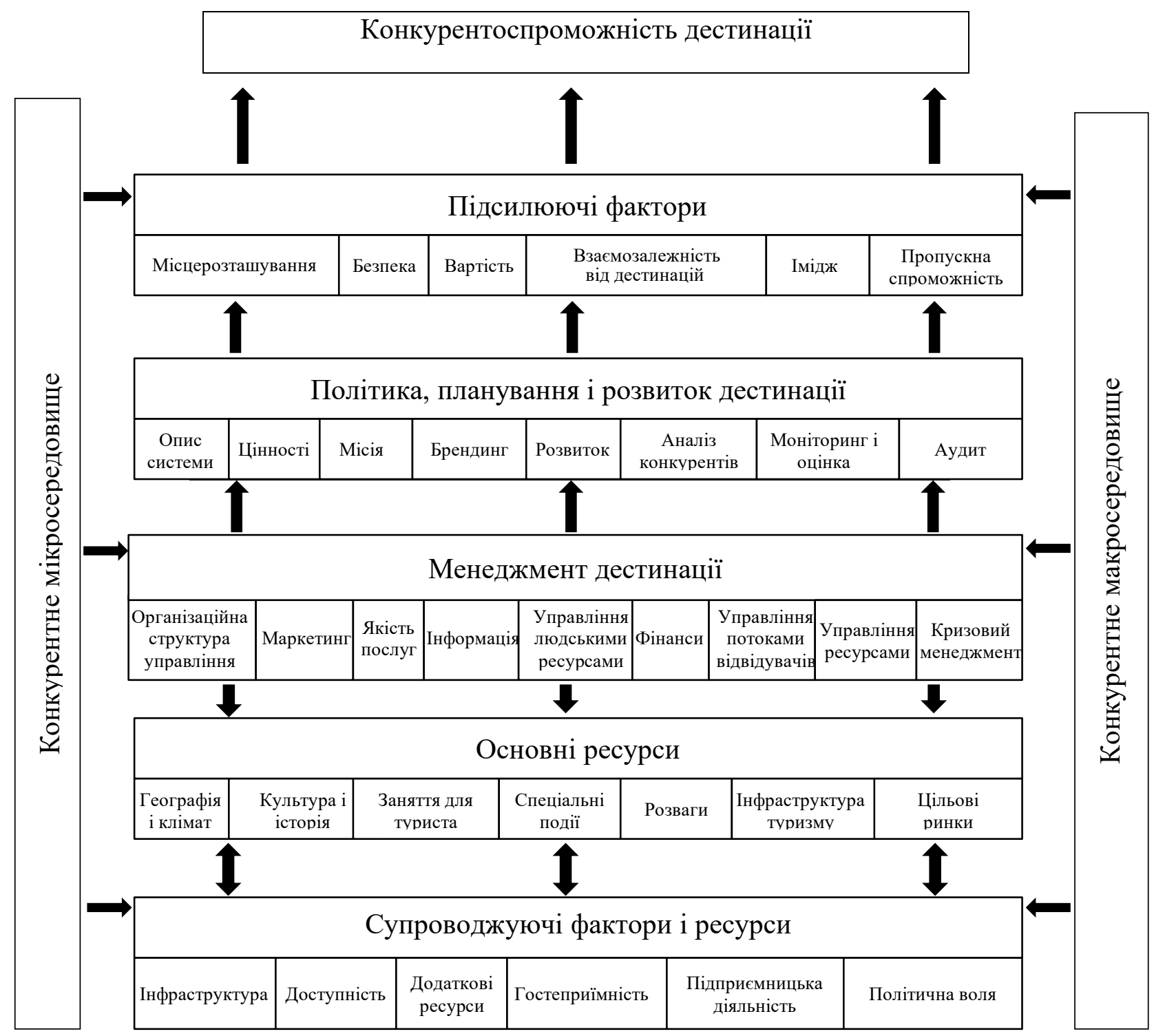

Рис. 1. Концепція конкурентоспроможності дестинації [5]. 
Головна мета менеджменту дестинації - це забезпечення довгострокової конкурентоспроможність дестинації.

Фактори конкурентоспроможності складаються 3 5-ти кластерів. У моделі визначено 36 параметрів, за якими оцінюється конкурентоспроможність дестинації.

Виявлення факторів конкурентоспроможності дестинації створює основу для іiі планування та розвитку, формування туристичної політики і стратегії. У цьому процесі має важливе значнггя організація з менеджменту дестинації.

Розглянемо головні особливості організацій з менеджменту дестинації на прикладі зарубіжного досвіду.

Організацією з менеджменту дестинації в Австріії є Австрійський національний туристичний офic (Austrian National Tourist Office), який був заснований Міністерством економіки та Торговою палатою Австрії.

Президентом Австрійського національного туристичного офісу $\epsilon$ міністр економіки і праці Австрії, віце-президентом - міністр туризму. Структура офісу складається з підрозділів: маркетингове агентство; управління по роботі з закордонними представництвами офісу; е-врядування - охоплює весь діапазон можливостей електронної торгівлі та маркетингу через інтернет.

Співвласники Австрійського національного туристичного офісу: $75 \%$ Австрійська Республіка; 25\% - торгово-промислова палата. Щороку Австрійський національний туристичний офіс проводить по всьому світу більше 1500 маркетингових заходів. Це реклама, PR-кампанії, участь у виставках, проведення семінарів, презентацій, workshops і багато іншого [6].

Австрійський національний туристичний офіс працює за такими напрямами[6]:

1) головним завданням у співпраці з австрійськими партнерами зі сфери туризму $\epsilon$ збереження і зміцнення конкурентоспроможності Австрії як туристичної країни. Таким чином, організвція здійснює серйозний внесок у збільшення частки Австрії на міжнародному туристичному ринку;

2) розвиток бренду «Відпустка в Австрії»: виділяє Австрію серед інших туристських дестинацій і повідомляє емоційну цінність перебування в Австрії;

3) вихід на найбільш перспективні міжнародні ринки за допомогою інноваційного та сучасного маркетингу. організацію представлено власними бюро в більшості країн Європи, в Росії, США, Китаї, Індії, Японії і Австралії;

4) наявність необхідної платформи маркетингової туристичної мережі: включення сфери туризму в програми маркетингових заходів щодо просування турпродукту Австрії, проведення маркетингових досліджень;

5) розробка i реалізація комплексу маркетингових комунікацій Австрії як туристської дестинації за допомогою роботи із засобами масової інформації, випуску тематичних проспектів, організації виставок і ярмарків;

6) організація навчання для представників туристичного бізнесу;

7) інформаційна підтримка туристів, здійснювана «Holiday Information Line» (найбільшим інформаційним сервісом про туризм в Австрії) i інтернет-порталом www.austria.info.

Австрійський національний туристичний офіс здебільшого фінансується державою. Державне фінансування, як правило, надходить у формі грантів. Крім державних асигнувань, бюджет організації може поповнюватися внесками партнерів 3 проведення маркетингових заходів, співпраці з підприємствами сфери туризму в області досліджень, членських внесків представників індустрії, відсотком від обслуговування туристів тощо. 
На регіональному рівні організацій з менеджменту дестинації DMOs активно залучають до вирішення завдань дестинації різних зацікавлених сторін (стейкхолдерів). Приватний сектор має можливість просування свого туристичного продукту 3 допомогою DMOs. Реалізуючи маркетингову роль, DMOs реалізовує маркетингову роль у посередництві між національними організаціями та туристської індустрією [7].

Якщо регіональна організація з менеджменту дестинації зможе об'єднати ресурси приватного і державного сектора, то вони водночас посилять стратегічний підхід та досягнуть великих результатів. Регіональна організація менеджменту дестинації повинна координувати і стимулювати роботу партнерів за допомогою розробки спільного плану менеджменту дестинації і контролювати виконання плану дій з туризму на регіональному рівні. Реалізуючи такі заходи, DMOs варто прислухатися до думки місцевого бізнесу і залучати його до процесу планування та виконання завдань.

Висновки. На підставі схваленої Стратегії розвитку туризму та курортів до 2026 року показано координацію механізмів та їхніх інструментів 3 напрямами стратегії розвитку туризму в Україні. Систематизовано механізми державного регулювання розвитку сфери туризму, їхні завдання й інструменти реалізації відповідно до державної стратегіï.

Формування ефективної системи розвитку менеджменту туризму відводить ключову роль туристичній дестинації, виконання якої можливе за умови акумуляції зусиль всіх стейкхолдерів туризму. Проаналізовано передову закордонну практику менеджменту дестинації, яка успішно реалізує принципи державно-приватного партнерства, дає змогу одержати економічний і соціальний ефект, зберегти туристичні ресурси, які залишились.

\section{Бібліографічний список}

Австрия. Официальный путеводитель, 2020. [онлайн] Доступно: $<$ http://www.austria.info/uk b2b/austrian-national-tourist-office> (дата обращения 25 жовтня 2020).

Горохов, А.Ф., 2007. Комплексный подход к формированию маркетинговой стратегии развития туристической дестинации. Канд. экон. наук. Автореферат. СанктПетербургский университет экономики и финансов.

Розпорядження Кабінету Міністрів України Про схвалення Стратегії розвитку туризму та курортів на період до 2026 року № 168-p, 2017. Урядовий портал. [онлайн] Доступно: <https://www.kmu.gov.ua/ua/npas/249826501> (дата звернення 25 жовтня 2020).

Cooper, C., Fletcher, J., Wanhill, S., Gilbert, D. and Shepherd, R., 2005. Tourism principles and practice. 3rd ed. Harlow, UK: Pearson Education.

Crouch, G.I., 2008. Modelling destination competitiveness : a survey and analysis of the impact of competitiveness attributes. Gold Coast, OLd: Sustainable Tourism CRC.

Leiper, N., 2004. Tourism management. 3rd ed. French Forest: Pearson Eduction Australia.

World Tourism Organization, 2007. A Practical Guide to Tourism Destination Management. Madrid: World Tourism Organization.

\section{References \\ Austria. The official travel portal, 2020. [online] Available at: $<$ https://www.austria.info/en_b2b/austrian-national-tourist-office $>$ (Accessed 15 October 2020).}

Cooper, C., Fletcher, J., Wanhill, S., Gilbert, D. and Shepherd, R., 2005. Tourism principles and practice. 3rd ed. Harlow, UK: Pearson Education. 
Crouch, G.I., 2008. Modelling destination competitiveness: a survey and analysis of the impact of competitiveness attributes. Gold Coast, OLd: Sustainable Tourism CRC.

Gorokhov, A.F., 2007. Kompleksnyy podkhod $k$ formirovaniyu marketingovoy strategii razvitiya turisticheskoy destinatsii [An integrated approach to the formation of a marketing strategy for the development of a tourist destination]. PhD. Abstract. Saint Petersburg State University of Economics.

Leiper, N., 2004. Tourism management. 3rd ed. French Forest: Pearson Eduction Australia.

Order of the Cabinet of Ministers of Ukraine On approval of the Tourism Development and Resorts Development Strategy for the period up to 2026 № 168-p, 2017. Government portal. [online] Available at: <www.kmu.gov.ua/ua/npas/249826501> (Accessed 15 October 2020). (in Ukrainian).

World Tourism Organization, 2007. A Practical Guide to Tourism Destination Management. Madrid: World Tourism Organization.

Стаття надійшла до редакції 21.09.2020

\section{O. Makara}

V. Maiboroda

\section{THE CURRENT STATE AND PECULIARITIES OF TOURISM MANAGEMENT DEVELOPMENT}

The article is devoted to the development of theoretical issues pertaining to the analysis of current state and trends in tourism management development, the disclosure of opportunities and prospects for the development of tourism, as well as the formation of scholarly and methodological prerequisites for its management development.

According to the ratified Strategy for the development of tourism and resorts by 2026 the coordination of mechanisms and tools with the direct strategy for the development of tourism in Ukraine has been explicated. The state regulation mechanisms of the sphere of tourism development, as well as the development of tools for the implementation of governmental strategy have been accordingly systematised. The organisational and economic mechanism of securing the Ukrainian tourist industry development has been suggested in this article.

The main directions of tourism management development have been established. The investigation of the development functions of tourism allowed estimating the predominant role of economic, social and ecologic functions.

The main principles for the development of tourism management have been established. Tourism is considered to be a system with internal and external environment. The internal body of tourist industry is represented by its organisational structure, personnel, marketing and finance whereas the external one includes political, economic, social, natural, and technological parts.

The formation of efficient system and development of tourism management is essentially predetermined by tourist destination, possible only when supported by all tourism stakeholders. The article analyses the leading world practice of tourist destinations with successfully implemented principle of state and private partnership.

Key words: tourism management, mechanism, instrument, tourism, tourist branch, the development of tourism, organisational mechanism, legal mechanism, economic mechanism, financial mechanism, state and private partnership. 